\title{
Transient Increase in Cellular Dehydrogenase Activity After Cadmium Treatment Precedes Enhanced Production of Reactive Oxygen Species in Human Proximal Tubular Kidney Cells
}

\author{
J. HANDL ${ }^{1}$, J. ČAPEK ${ }^{1}$, P. MAJTNEROVÁ ${ }^{1}$, F. PETIRA ${ }^{1}$, M. HAUSCHKE ${ }^{1}$, \\ E. ROUŠAROVÁ ${ }^{1}, T$. ROUŠAR ${ }^{1}$ \\ ${ }^{1}$ Department of Biological and Biochemical Sciences, Faculty of Chemical Technology, University \\ of Pardubice, Pardubice, Czech Republic
}

Received January 18, 2019

Accepted February 5, 2019

Epub Ahead of Print March 22, 2019

\section{Summary}

Cadmium is a heavy metal causing toxicity especially in kidney cells. The toxicity is linked also with enhanced oxidative stress leading to cell death. On the other hand, our recent experiments have shown that an increase of total intracellular dehydrogenases activity can also occur in kidney cells before declining until cell death. The aim of the present study, therefore, was to evaluate this transient enhancement in cell viability after cadmium treatment. The human kidney HK-2 cell line was treated with $\mathrm{CdCl}_{2}$ at concentrations $0-200 \mu \mathrm{M}$ for $2-24 \mathrm{~h}$ and intracellular dehydrogenase activity was tested. In addition, we measured reactive oxygen species (ROS) production, glutathione levels, mitochondrial membrane potential, and C-Jun-N-terminal kinase (JNK) activation. We found that significantly increased dehydrogenase activity could occur in cells treated with 25, 100, and $200 \mu \mathrm{M} \mathrm{CdCl}_{2}$. Moreover, the results showed an increase in ROS production linked with JNK activation following the enhancement of dehydrogenase activity. Other tests detected no relationship with the increased in intracellular dehydrogenase activity. Hence, the transient increase in dehydrogenase activity in HK-2 cells preceded the enhancement of ROS production and our finding provides new evidence in cadmium kidney toxicity.

\section{Key words}

Cadmium toxicity - Kidney injury - Dehydrogenase activity • Oxidative stress $\bullet$ ROS production

\section{Corresponding author}

T. Roušar, Department of Biological and Biochemical Sciences, Faculty of Chemical Technology, University of Pardubice,
Studentská 573, 53210 Pardubice, Czech Republic. Fax: +420 466037 068. E-mail: Tomas.Rousar@upce.cz

\section{Introduction}

Cadmium is a widely occurring, highly toxic heavy metal. It can be toxic even at low concentrations (Tobwala et al. 2014). The toxic effect of cadmium is most commonly detected in kidney, liver, and neuronal cells (Linhartová et al. 2016, Wang et al. 2007). In addition, the toxicity can be found in bone and blood cells (Fahim et al. 2012, Fongsupa et al. 2015, Klaassen et al. 2009, Li et al. 2016, Madden et al. 2002, Zhang et al. 2007).

Cadmium (i.e. cadmium ion) causes both acute and chronic toxic effects in the organism. These effects are mostly linked with induction of oxidative stress (Thévenod and Friedmann 1999, Tobwala et al. 2014). Therefore, $\mathrm{Cd}$ is able significantly to decrease the levels of glutathione (GSH), a major intracellular nonprotein thiol (López et al. 2006, Zahir et al. 1999). In addition, some reports have indicated that low $\mathrm{Cd}$ concentrations induce mutations through DNA oxidative damage and by diminishing the genetic stability of cells (Valverde et al. 2001). These events increase the probability of mutations and, consequently, initiation of tumor growth (Filipič 2012).

Recently, a human immortalized proximal tubular cell line (HK-2) has been developed for studying nephrotoxicity in vitro (Gunness et al. 2010, Ryan et al. 
1994). The HK-2 cells also have been used for testing nephrotoxicity of heavy metals, including Cd (Shrestha et al. 2017, Wilmes et al. 2011). Acute exposure of HK-2 cells to $\mathrm{Cd}$ leads to apoptosis of those cells (Mao et al. 2007, Shrestha et al. 2017), as Cd induces the expression and activation of pro-apoptotic proteins, including caspases (Huang et al. 2017). A number of studies have reported that $\mathrm{Cd}$ can induce both apoptotic and necrotic cell death (Kondo et al. 2012). Necrosis and apoptosis are linked with lipid peroxidation and increased reactive oxygen species (ROS) production induced by Cd (López et al. 2006). The reports have proven that higher ROS production induces phosphorylation of C-Jun-N-terminal kinase (JNK) in human renal proximal tubular cells (Fongsupa et al. 2015). All these processes can lead to decrease of cell viability and even to cell death.

The goal of the present study is directly linked to the results of our previous study (Hauschke et al. 2017), whereby we recently found that $\mathrm{Cd}$ treatment, surprisingly, can also lead to temporary increase in the viability of HK-2 cells. Indications of increase in cell viability after $\mathrm{Cd}$ treatment can be found also in reports from other authors (Iwatsuki et al. 2011, Lee et al. 2015, Somji et al. 2006), but none of the previous studies had given much attention to this finding. Therefore, the aim of the present study was to examine whether the increase in HK-2 cell viability after $\mathrm{Cd}$ exposure is related to $\mathrm{Cd}$ concentration and/or duration of $\mathrm{Cd}$ treatment, as well as whether the increase of total intracellular dehydrogenases activity (further referred as dehydrogenase activity) can be linked to any other changes in oxidative metabolism.

\section{Materials and Methods}

\section{Chemicals}

Dulbecco's Modified Eagle's Medium/Nutrient Mixture F-12 (with/without phenol red), insulin, transferrin, and sodium selenite were purchased from Sigma-Aldrich (USA). Fetal bovine serum, pyruvate, penicillin, streptomycin, epidermal growth factor, and all other chemicals, if not otherwise specified, were purchased from Invitrogen-Gibco (USA).

\section{Cell culture}

Human kidney (HK-2) cells, a proximal tubular epithelial cell line derived from normal adult human kidney cells immortalized by transduction with human papillomavirus (HPV 16) DNA fragment (Ryan et al.
1994), were purchased from the American Type Culture Collection (ATCC, Manassas, VA, USA). The cells were cultured in keeping with our previous studies (Hauschke et al. 2017, Vrbová et al. 2016). All the experiments were conducted using the HK-2 cells (passages 4-11). HK-2 cells were seeded into 96-well plates at density of $3 \times 10^{4}$ cells/well and exposure medium containing 0-1 $\mathrm{mM} \mathrm{CdCl}{ }_{2}$. The cells were incubated for specific periods of 2, 6, 10, 24 and $48 \mathrm{~h}$.

\section{Dehydrogenase activity measurement}

Dehydrogenase activity was evaluated by WST-1 test (Roche, Germany). The WST-1 test measures the activity of intra- and extramitochondrial dehydrogenases. At the required time, the WST-1 reagent was added to the cultured cells (1:10 final dilution). The cells were incubated in a gassed atmosphere $\left(5 \% \mathrm{CO}_{2}\right)$ for $60 \mathrm{~min}$ and the absorbance change $(0-1 \mathrm{~h})$ was measured spectrophotometrically at wavelength of $440 \mathrm{~nm}$ using a Tecan Infinite M200 plate reader (Tecan, Austria). The dehydrogenase activity was expressed as the percentage intra- and extramitochondrial dehydrogenases activity relative to that in control cells (=100\%).

\section{Measuring glutathione levels}

GSH levels were measured using an optimized bimane assay (Čapek et al. 2017). The cells were incubated in cell medium $(100 \mu \mathrm{l})$ on 96 -well plates with $\mathrm{CdCl}_{2}$ for an appropriate time. After incubation, $20 \mu \mathrm{l}$ of the bimane solution was added to cells and measurement was started. The final concentration of monochlorobimane in a well was $40 \mu \mathrm{M}$. The fluorescence $(E x / E m=394 / 490 \mathrm{~nm})$ was measured for $20 \mathrm{~min}$ using a Tecan Infinite M200 fluorescence reader incubated at $37{ }^{\circ} \mathrm{C}$. The fluorescence was expressed as the slope of change in fluorescence over time. The GSH levels were expressed as the percentage relative to those in control cells $(=100 \%)$.

\section{Measuring ROS production}

We used chloromethyl-2',7'-dichlorodihydrofluorescein diacetate (CM- $\mathrm{H}_{2}$ DCFDA; Thermo, USA) as an intracellular probe to detect ROS production. The working solution was prepared fresh at the time of analysis by dilution in Dulbecco's Modified Eagle's Medium. The cells were incubated with $\mathrm{CdCl}_{2}$ for appropriate periods. After incubation, the $\mathrm{CM}-\mathrm{H}_{2}$ DCFDA working solution was added to cells to be loaded with the 
probe for $90 \mathrm{~min}$. The final concentration of $\mathrm{CM}-\mathrm{H}_{2}$ DCFDA in a well was $1 \mu \mathrm{M}$. The cells were then washed with phosphate buffered saline (PBS) and the fluorescence measurement was started. The fluorescence $(\mathrm{Ex} / \mathrm{Em}=485 / 535 \mathrm{~nm})$ was measured for $60 \mathrm{~min}$ using a Tecan Infinite M200 fluorescence reader. The ROS levels were expressed as the percentage relative to ROS levels in control cells (=100\%).

\section{Detecting mitochondrial membrane potential}

Mitochondrial membrane potential was measured using a JC-1 intracellular probe. The working solution of JC-1 was prepared fresh at the time of analysis by dilution in Dulbecco's phosphate buffer. After Cd treatment, $20 \mu \mathrm{l}$ of the JC-1 solution was added to cells. The final concentration of JC-1 in a well was $10 \mu \mathrm{g} / \mathrm{ml}$. The HK-2 cells were loaded for $20 \mathrm{~min}$ and then washed with PBS. The fluorescence (red: $\mathrm{Ex} / \mathrm{Em}=485 / 595 \mathrm{~nm}$; green: $\mathrm{Ex} / \mathrm{Em}=485 / 535 \mathrm{~nm}$ ) was measured using a Tecan Infinite M200 fluorescence reader. The rate of mitochondrial membrane potential was expressed as the red/green ratio.

\section{Measuring nuclear condensation}

We used Hoechst 33258 dye for detecting DNA fragmentation in cells. The working solution of Hoechst 33258 was prepared fresh at the time of analysis. After Cd treatment, $10 \mu \mathrm{l}$ of the Hoechst 33258 solution was added to cells and the fluorometric measurement was started after $20 \mathrm{~min}$ of loading. The final concentration of Hoechst 33258 in a well was $2 \mu \mathrm{g} / \mathrm{ml}$. The fluorescence $(\mathrm{Ex} / \mathrm{Em}=352 / 461 \mathrm{~nm})$ was measured using a Tecan Infinite M200 fluorescence reader. The fluorescence signal was expressed as the percentage relative to fluorescence in control cells $(=100 \%)$.

\section{Measuring caspase-3/7 activity}

Caspase-3/7 activation was measured by Apo$\mathrm{ONE}^{\circledR} \quad$ Homogeneous Caspase-3/7 Assay (Promega, USA). The working solution of caspase-3/7 was prepared fresh at the time of analysis. The cells were incubated with $\mathrm{CdCl}_{2}$ and cisplatin $(100 \mu \mathrm{M})$ for appropriate times. Then, $100 \mu \mathrm{l}$ of the caspase-3/7 working solution was added to cells and the fluorescence $(E x / E m=485 / 530 \mathrm{~nm})$ was measured using a Tecan Infinite M200 fluorescence reader. At $14 \mathrm{~h}$ of treatment, the fluorescence was expressed as the percentage relative to the fluorescence in control cells $(=100 \%)$.

\section{Detecting protein levels}

The protein levels of $\mathrm{JNK}$ and $\mathrm{NF} \kappa \mathrm{B}$ were detected using western blot analysis. Briefly, HK-2 cells $\left(1.5 \times 10^{6}\right)$ were washed in PBS, lysed in RIPA Lysis Buffer $\left(30 \mathrm{~min} ; 4^{\circ} \mathrm{C}\right)$, centrifuged $(16,000 \times \mathrm{g} ; 20 \mathrm{~min}$; $4{ }^{\circ} \mathrm{C}$ ), and the supernatant was loaded onto SDS-PAGE. Proteins were transferred onto Immun-Blot PVDF Membrane (Bio-Rad, USA). After blocking in TBST buffer (20 mM TRIS; $150 \mathrm{mM} \mathrm{NaCl} ; 0.1 \%$ Tween-20; $\mathrm{pH} 7.5$ ) containing $5 \%$ bovine serum albumin, the samples were incubated with Anti-ACTIVE® JNK (anti-54 kDa JNK2; Rabbit; Promega), Anti-NFאB p65 monoclonal antibodies (Mouse; Invitrogen) or anti-B-Actin (Rabbit; Sigma-Aldrich) according to the manufacturer's instructions. The membrane was then incubated with horseradish peroxidase-conjugated secondary antibodies (Goat; Sigma-Aldrich, Goat anti-mouse; Invitrogen). The proteins were visualized using Clarity ${ }^{\mathrm{TM}}$ Western ECL Substrate (Bio-Rad) and ChemiDoc ${ }^{\mathrm{TM}}$ MP System (Bio-Rad).

\section{Statistics}

All experiments were repeated at least three times independently. All values were measured at least in duplicate. The results are expressed as mean $\pm \mathrm{SD}$. Statistical significance was analyzed after normality testing using one-way analysis of variance (ANOVA) followed by Bonferroni correction (OriginPro 9.0.0, USA). In comparing results with control cells without cadmium treatment, the significance level was set at $p=0.05$ or lower $(* p<0.05 ; * * p<0.01 ; * * * p<0.001)$.

\section{Results}

Based on the results reported in our previous study (Hauschke et al. 2017), we aimed to characterize the toxic effect of $\mathrm{Cd}$ across a broad range of $\mathrm{CdCl}_{2}$ concentrations. The $\mathrm{HK}-2$ cells were treated with $\mathrm{CdCl}_{2}$ $(0.1 \mu \mathrm{M}-1 \mathrm{mM})$ for 6 and $24 \mathrm{~h}$, and intracellular dehydrogenase activity was measured using the WST-1 test. After $6 \mathrm{~h}$, we detected in cells treated with $200 \mu \mathrm{M}$ and $1 \mathrm{mM} \mathrm{CdCl}_{2}$ a significant reduction of cellular dehydrogenase activity to $19 \pm 2 \%(p<0.001)$ and $80 \pm 8 \%$ $(p<0.001)$, respectively, in comparison with controls $(=100 \%)$. On the other hand, significant increase in cell viability was found in cells treated with $25 \mu \mathrm{M}$

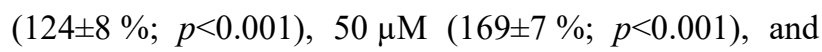
$100 \mu \mathrm{M} \mathrm{CdCl} 2(152 \pm 9 \% ; p<0.001)$ in comparison to control cells (Fig. 1). After 24 h, the significant decrease 
in cell viability was found in cells treated with 100,200 , and $1,000 \mu \mathrm{M} \mathrm{CdCl}_{2}$ (Fig. 2). The viability of HK-2 cells treated with $25 \mu \mathrm{M}$ and $50 \mu \mathrm{M} \mathrm{CdCl}_{2}$ increased significantly to $128 \pm 18 \% \quad(p<0.001)$ and $163 \pm 9 \%$ $(p<0.001)$, respectively, in comparison with controls.
Based on these results, we have proven that, under the given conditions, the HK-2 cells could exhibit enhanced intracellular dehydrogenase activity after $\mathrm{CdCl}_{2}$ treatment as opposed to the expected diminished intracellular dehydrogenase activity.

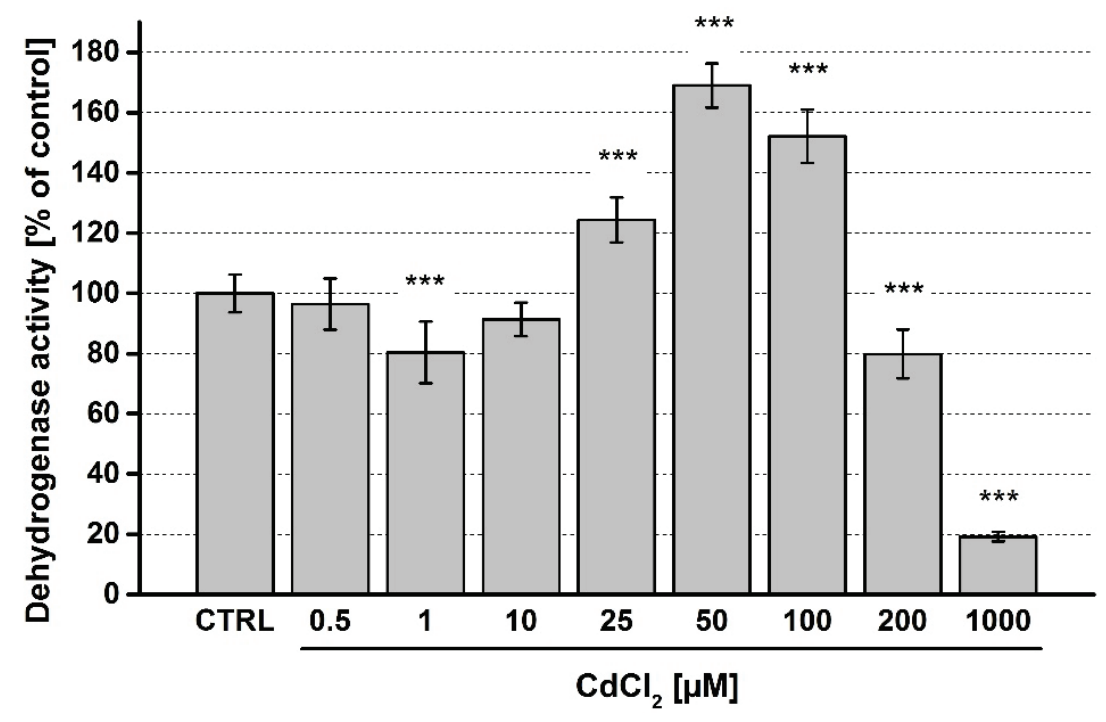

Fig. 1. Dehydrogenase activity measurement - HK-2 cells were assayed using the WST-1 test after $6 \mathrm{~h}$ of treatment with $\mathrm{CdCl}_{2}$ at concentrations $0-1,000 \mu \mathrm{M}$. The results are expressed as mean \pm SD (control $=100 \% ; \mathrm{n}=6-10$ ). ${ }^{* * *} p<0.001$ (compared to control).

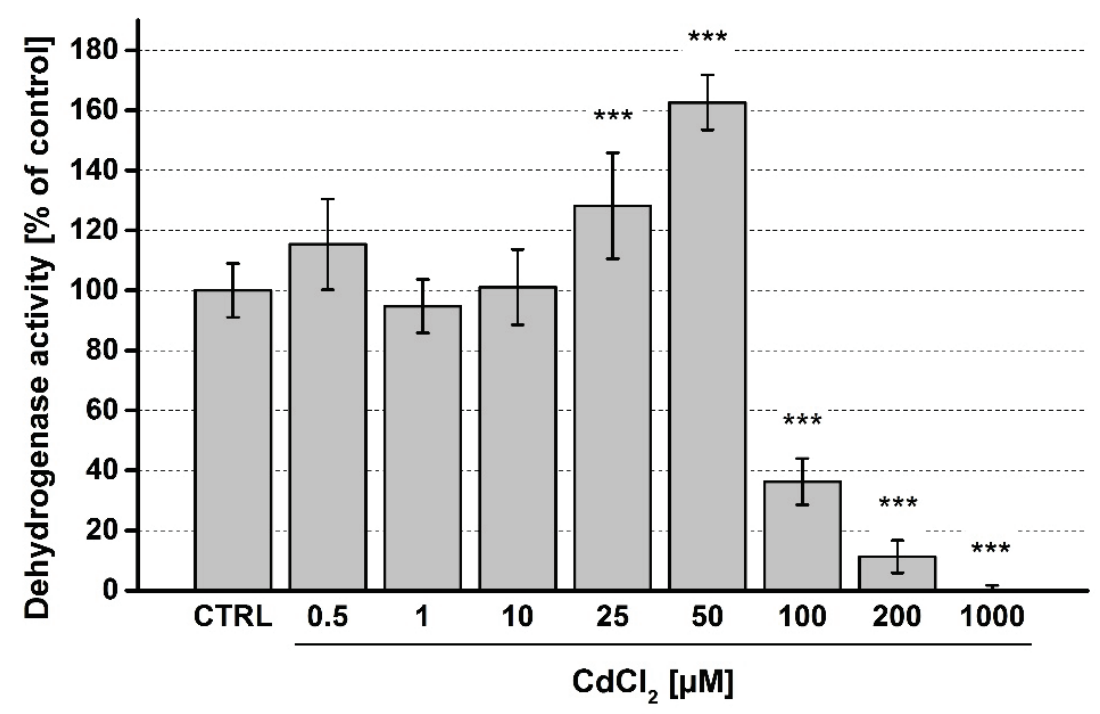

Fig. 2. Dehydrogenase activity measurement - HK-2 cells were assayed using the WST-1 test after $24 \mathrm{~h}$ of treatment with $\mathrm{CdCl}_{2}$ at concentrations $\quad 0-1,000 \mu \mathrm{M}$. The results are expressed as mean \pm SD (control=100 \%; $\mathrm{n}=6-10)$. ${ }^{* * *} p<0.001$ (compared to control).

We selected treatments of 5, 25, 100, and $200 \mu \mathrm{M} \mathrm{CdCl}{ }_{2}$ for the following characterization of changes in dehydrogenase activity of $\mathrm{HK}-2$ cells incubated with $\mathrm{CdCl}_{2}$ for 2, 6, 10, and $24 \mathrm{~h}$. We first tested again intracellular dehydrogenase activity using WST-1 (Table 1). With the exception of the $5 \mu \mathrm{M}$ treatment, we detected significant increase in intracellular dehydrogenase activity that was dependent on incubation time in all tested $\mathrm{CdCl}_{2}$ concentrations. The increased in dehydrogenase activity was strongly related to both
$\mathrm{CdCl}_{2}$ dose and duration of treatment. In the case of cells treated with $200 \mu \mathrm{M} \mathrm{CdCl}$, a significant increase in intracellular dehydrogenase activity was detected only after $2 \mathrm{~h}$. Longer treatment times with $200 \mu \mathrm{M} \mathrm{CdCl}{ }_{2}$ caused a decrease in dehydrogenase activity of $\mathrm{HK}-2$ cells. Treatment with $100 \mu \mathrm{M} \mathrm{CdCl}_{2}$ caused a significant increase in intracellular dehydrogenase activity after 2,6 , and $10 \mathrm{~h}$ but a significant decrease after $24 \mathrm{~h}$. In cells treated with $25 \mu \mathrm{M} \mathrm{CdCl}$, increase in intracellular dehydrogenase activity was detected only after treatment 
from 6 to $24 \mathrm{~h}$.

Because the increase in dehydrogenase activity detected using the WST-1 test could be related to changes in oxidative metabolism, we assessed mitochondrial membrane potential, GSH levels, and ROS production (Table 2). To assess oxidative stress after $\mathrm{CdCl}_{2}$ treatment, we measured intracellular ROS production.
We found that ROS production was considerably related to outcomes of increased dehydrogenase activity. The results showed that ROS production was increased significantly in cells treated with $200 \mu \mathrm{M} \mathrm{CdCl}_{2}$ after both 2 and $6 \mathrm{~h}$. At 6 and $24 \mathrm{~h}$, ROS production was increased in those cells treated with 100 and $25 \mu \mathrm{M}$ $\mathrm{CdCl}_{2}$, respectively (Table 2).

Table 1. Dehydrogenase activity of HK-2 cells.

\begin{tabular}{lccccc}
\hline \multirow{2}{*}{ Time } & \multicolumn{5}{c}{$\mathbf{C d C l}_{\mathbf{2}}(\boldsymbol{\mu M})$} \\
\cline { 2 - 6 } & $\mathbf{0}$ & $\mathbf{5}$ & $\mathbf{2 5}$ & $\mathbf{1 0 0}$ & $\mathbf{2 0 0}$ \\
\hline $2 h$ & $100 \pm 7 \%$ & $79 \pm 7 \% * * *$ & $96 \pm 7 \%$ & $138 \pm 10 \% * * *$ & $114 \pm 4 \% *$ \\
$6 h$ & $100 \pm 6 \%$ & $80 \pm 9 \% * * *$ & $124 \pm 8 \% * * *$ & $152 \pm 9 \% * * *$ & $80 \pm 8 \% * * *$ \\
$10 h$ & $100 \pm 5 \%$ & $101 \pm 5 \%$ & $139 \pm 6 \% * * *$ & $173 \pm 7 \% * * *$ & $80 \pm 5 \% * * *$ \\
$24 h$ & $100 \pm 9 \%$ & $92 \pm 6 \%$ & $128 \pm 18 \% * * *$ & $36 \pm 8 \% * * *$ & $11 \pm 5 \% * * *$ \\
$48 h$ & $100 \pm 10 \%$ & $102 \pm 4 \%$ & $101 \pm 3 \%$ & $2 \pm 0 \% * * *$ & $0 \% * * *$ \\
\hline
\end{tabular}

The activity was assayed using the WST-1 test after 2, 6, 10, 24 and $48 \mathrm{~h}$ of treatment with $\mathrm{CdCl}_{2}$ at concentrations $0-200 \mu \mathrm{M}$. Gray shading indicates the finding of increased intracellular dehydrogenase activity. The results are expressed as mean \pm SD (control $=100 \% ; \mathrm{n}=6-10$ ). $* p<0.05 ; * * * p<0.001$.

Table 2. Estimation of oxidative metabolism in $\mathrm{HK}-2$ cells after $\mathrm{CdCl}_{2}$ treatment (0-200 $\left.\mu \mathrm{M}\right)$ for 2, 6, 10, and $24 \mathrm{~h}$.

\begin{tabular}{|c|c|c|c|c|c|}
\hline Time & $\mathrm{CdCl}_{2}(\mu \mathrm{M})$ & ROS & GSH & MMP (R/G) & DNA condensation \\
\hline \multirow{5}{*}{$2 h$} & 0 & $100 \pm 13 \%$ & $100 \pm 5 \%$ & $2.29 \pm 0.11$ & $100 \pm 11 \%$ \\
\hline & 5 & $60 \pm 6 \% * * *$ & $102 \pm 4 \%$ & $2.17 \pm 0.13$ & $94 \pm 15 \%$ \\
\hline & 25 & $57 \pm 9 \% * * *$ & $99 \pm 3 \%$ & $2.45 \pm 0.18$ & $65 \pm 13 \% * *$ \\
\hline & 100 & $49 \pm 12 \% * * *$ & $93 \pm 1 \%$ & $2.07 \pm 0.14$ & $59 \pm 9 \% * * *$ \\
\hline & 200 & $148 \pm 13 \% * * *$ & $87 \pm 4 \% * * *$ & $1.98 \pm 0.11^{* *}$ & $61 \pm 17 \% * * *$ \\
\hline \multirow{5}{*}{$6 h$} & 0 & $100 \pm 14 \%$ & $100 \pm 4 \%$ & $2.16 \pm 0.31$ & $100 \pm 50 \%$ \\
\hline & 5 & $90 \pm 9 \%$ & $97 \pm 4 \%$ & $2.45 \pm 0.19$ & $107 \pm 28 \%$ \\
\hline & 25 & $69 \pm 5 \% * *$ & $97 \pm 3 \%$ & $2.02 \pm 0.09$ & $98 \pm 5 \%$ \\
\hline & 100 & $189 \pm 14 \% * * *$ & $79 \pm 3 \% * * *$ & $2.41 \pm 0.25$ & $82 \pm 31 \%$ \\
\hline & 200 & $311 \pm 21 \% * * *$ & $59 \pm 3 \% * * *$ & $2.45 \pm 0.25$ & $87 \pm 44 \%$ \\
\hline \multirow{5}{*}{$10 \mathrm{~h}$} & 0 & N/A & $100 \pm 4 \%$ & $2.57 \pm 0.33$ & $100 \pm 30 \%$ \\
\hline & 5 & $\mathrm{~N} / \mathrm{A}$ & $99 \pm 3 \%$ & $2.40 \pm 0.34$ & $69 \pm 26 \%$ \\
\hline & 25 & $\mathrm{~N} / \mathrm{A}$ & $105 \pm 2 \%$ & $1.94 \pm 0.26^{*}$ & $70 \pm 21 \%$ \\
\hline & 100 & N/A & $59 \pm 3 \% * * *$ & $2.46 \pm 0.17$ & $54 \pm 17 \%$ \\
\hline & 200 & $\mathrm{~N} / \mathrm{A}$ & $39 \pm 2 \% * * *$ & $1.49 \pm 0.11^{* * *}$ & $563 \pm 26 \% * * *$ \\
\hline \multirow{5}{*}{$24 h$} & 0 & $100 \pm 14 \%$ & $100 \pm 3 \%$ & $2.16 \pm 0.27$ & $100 \pm 13 \%$ \\
\hline & 5 & $86 \pm 5 \%$ & $102 \pm 4 \%$ & $1.80 \pm 0.12$ & $74 \pm 16 \%$ \\
\hline & 25 & $204 \pm 23 \% * * *$ & $102 \pm 4 \%$ & $1.62 \pm 0.13 * *$ & $86 \pm 8 \%$ \\
\hline & 100 & $78 \pm 12 \%$ & $7 \pm 1 \% * * *$ & $0.31 \pm 0.07 * * *$ & $529 \pm 64 \% * * *$ \\
\hline & 200 & $88 \pm 15 \%$ & $5 \pm 1 \% * * *$ & $0.22 \pm 0.03 * * *$ & $561 \pm 36 \% * * *$ \\
\hline
\end{tabular}

Reactive oxygen species (ROS) levels were assessed using chloromethyl-2',7'-dichlorodihydrofluorescein diacetate probe. Glutathione (GSH) levels were measured using monochlorobimane. The mitochondrial membrane potential (MMP) was measured by fluorometric method using the JC-1 probe and the results were expressed as the red/green (R/G) ratio. Nuclear condensation was measured using Hoechst 33258 probe. The results are expressed as mean \pm SD (control=100 \%; $\mathrm{n}=6-10)$. ${ }^{*} p<0.05 ; * * p<0.01 ; * * * p<0.001$. 
We found no significant change of MMP in relation to the observed increase in intracellular dehydrogenase activity after $\mathrm{CdCl}_{2}$ treatment. Our experiments showed that MMP was significantly reduced mostly after treatment with $\mathrm{CdCl}_{2}$ for longer periods. Therefore, the change of MMP in HK-2 cells was rather unrelated to the $\mathrm{CdCl}_{2}$-induced increase in intracellular dehydrogenase activity. Significant changes in cellular GSH levels were detected in treatments using $200 \mu \mathrm{M}$ $\mathrm{CdCl}_{2}$ for all tested time periods. Similar GSH depletion was detected in cells treated with $100 \mu \mathrm{M} \mathrm{CdCl}_{2}$. No changes of GSH levels were found in treatments using 5 and $25 \mu \mathrm{M} \mathrm{CdCl}$.

Finally, we examined changes in cell nucleus induced by $\mathrm{CdCl}_{2}$ using three methods: detecting DNA condensation, measuring caspase activity, and assessing JNK activation. We found significantly increased fluorescence signal of DNA condensation in cells treated with $200 \mu \mathrm{M} \mathrm{CdCl}_{2}$ after both 10 and $24 \mathrm{~h}$ and in cells treated with $100 \mu \mathrm{M} \mathrm{CdCl}{ }_{2}$ after $24 \mathrm{~h}$ (Table 2). The examination of caspase activities showed the activity of caspase $3 / 7$ to be non-significantly increased after $200 \mu \mathrm{M} \mathrm{CdCl}_{2}$ treatment (data not shown). JNK activation was detected using western blot analysis. Increased protein levels of $\mathrm{p}$-JNK were detected after 2, 6 and $10 \mathrm{~h}$ in both the 100 and $200 \mu \mathrm{M}$ treatments. At $24 \mathrm{~h}$, JNK activation was detected at all tested $\mathrm{CdCl}_{2}$ concentrations with the exception $200 \mu \mathrm{M} \mathrm{CdCl}$ treated cells (Fig. 3). In addition, we detected NFkB activation in Cd treated HK-2 cells, but the results did not show any changes in the NFkB expression.

\section{Discussion}

The toxicity of $\mathrm{Cd}$ has been tested in renal cell lines of human (i.e. HK-2 cells; Fujiki et al. 2013, Kim et al. 2014, Simon et al. 2014, Wilmes et al. 2011) and animal origin (i.e. canine MDCK; Zimmerhackl et al. 1998), pig LLC-PK1 (Fotakis and Timbrell 2006), rat HTC (Gennari et al. 2003). HK-2 cells are immortalized proximal tubular cells (Gunness et al. 2010) and presently are regarded as providing the most relevant model for studying Cd toxicity (Fongsupa et al. 2015, Fujiki et al. 2013, Huang et al. 2017, Iwatsuki et al. 2011, Komoike et al. 2011, Shrestha et al. 2017, Somji et al. 2006). Therefore, HK-2 cells were used for characterizing $\mathrm{Cd}$ cytotoxicity in the study we present here.

Our results have shown that, contrary to expected decrease in cell viability, $\mathrm{CdCl}_{2}$ can induce
$\mathrm{CdCl}_{2}[\mu \mathrm{M}]$

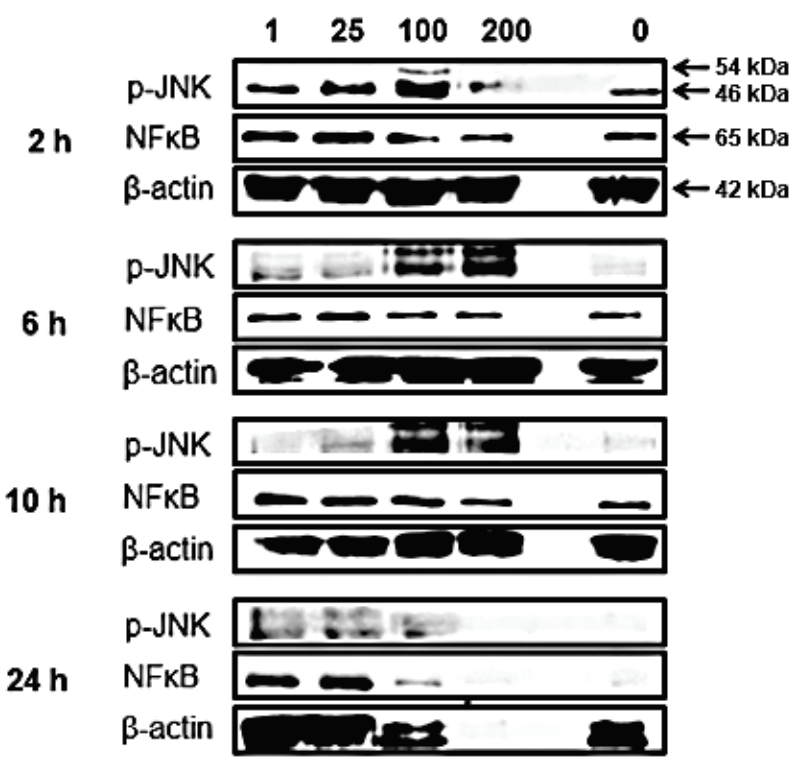

Fig. 3. Detection of $\mathrm{p}-\mathrm{JNK}$ and $\mathrm{NFkB}$ in $\mathrm{HK}-2$ cells after $\mathrm{CdCl}_{2}$ exposure using western blot analysis. Cells were exposed to different concentrations of $\mathrm{CdCl}_{2}(1-200 \mu \mathrm{M})$ for $2,6,10$, and 24 h. $\beta$-actin (42 kDa), NFkB (65 kDa), p-JNK (46 kDa, 54 kDa) were determined for each interval and concentration (with comparison to control cells).

a transient increase of cell viability in relation to $\mathrm{CdCl}_{2}$ dose and incubation time (Hauschke et al. 2017). In addition, some outcomes from several studies by other authors also lend support to our findings. Enhanced cell viability after $\mathrm{Cd}$ treatment has been reported from studies using both human (Iwatsuki et al. 2011, Kondo et al. 2012) and animal (Fotakis and Timbrell 2006, Riemschneider et al. 2015) kidney cells as well as cells of other tissue origin (Bonham et al. 2003, Somji et al. 2006). Because those reports provided no information on the finding of increased in intracellular dehydrogenase activity after $\mathrm{Cd}$ treatment, we decided to characterize that role of $\mathrm{CdCl}_{2}$.

We tested treatment of $\mathrm{HK}-2$ cells with $\mathrm{CdCl}_{2}$ in a variety of concentrations $(5,25,100$, and $200 \mu \mathrm{M}$ $\mathrm{CdCl}_{2}$ ) and times (2-24 h). Intracellular dehydrogenase activity was detected using the WST-1 test, which measures the activity of intracellular dehydrogenases. We found that all tested concentrations of $\mathrm{CdCl}_{2}$ with the exception of $5 \mu \mathrm{M}$ induced significant transient increase in intracellular dehydrogenase activity in HK-2 cells and that the time of the occurrence of dehydrogenase activity increase was inversely correlated with $\mathrm{CdCl}_{2}$ concentration. Our results can also be supported by outcomes from two other studies (Iwatsuki et al. 2011, 
Kondo et al. 2012) which tested $\mathrm{CdCl}_{2}$-induced changes in HK-2 dehydrogenase activity using the WST-8 test. The induction of increased $\mathrm{HK}-2$ dehydrogenase activity was found in cells treated with $20 \mu \mathrm{M} \mathrm{CdCl}_{2}$ for $4 \mathrm{~h}$. Unfortunately, those two studies did not use $\mathrm{CdCl}_{2}$ at levels higher than $50 \mu \mathrm{M}$. Two other studies on cadmium toxicity reported the increased in intracellular dehydrogenase activity after exposure to $10 \mu \mathrm{M} \mathrm{CdCl}{ }_{2}$ for 24 and $48 \mathrm{~h}$ in an animal MDCK kidney cell line (Bonham et al. 2003) and after treatment with $10 \mu \mathrm{M}$ $\mathrm{CdCl}_{2}$ for 24 and $48 \mathrm{~h}$ in the RAW 264.7 macrophage cell line (Riemschneider et al. 2015).

Seeking the implication of the cell viability increase in HK-2 cells, we followed the experiments with additional biochemical tests. Because the increase of intracellular dehydrogenase activity could be related to changes in redox metabolism, we assessed ROS production, GSH levels, MMP, and JNK activation. Intracellular ROS production and GSH levels were measured as markers of oxidative stress. We found that induction of ROS production followed the enhancement of dehydrogenase activity as measured by the WST-1 test in $\mathrm{CdCl}_{2}$-treated $\mathrm{HK}-2$ cells. After $2 \mathrm{~h}$, increase in dehydrogenase activity and ROS production were detected in cells treated with $200 \mu \mathrm{M} \mathrm{CdCl}_{2}$. Inasmuch as the $100 \mu \mathrm{M}$ treatment induced increased dehydrogenase activity after $2 \mathrm{~h}$ and $6 \mathrm{~h}$ but ROS production was stimulated significantly only after $6 \mathrm{~h}$, we might conclude that increase in intracellular dehydrogenase activity precludes the increase in ROS production. This can be supported by the finding that intracellular dehydrogenase activity of $\mathrm{HK}-2$ cells incubated in $25 \mu \mathrm{M} \mathrm{CdCl}{ }_{2}$ increased after 6 and $24 \mathrm{~h}$ but ROS production was stimulated significantly until $24 \mathrm{~h}$. Another conclusion from our results is that significant depletion of intracellular GSH levels appeared in all incubation periods only after increase in ROS production. In contrast, after $24 \mathrm{~h}$ of treatment of HK-2 cells with $25 \mu \mathrm{M} \mathrm{CdCl}_{2}$, the increase in intracellular dehydrogenase activity and ROS production was not linked with GSH depletion. This might be because such short duration of treatment did not allow the GSH depletion to appear.

To characterize other cellular processes related to increased dehydrogenase activity of HK-2 cells after $\mathrm{Cd}$ treatment, we used detection of JNK and NFkB activation. We found no changes in NFkB protein expression. On the other hand, our results showed increased p-JNK levels in cells treated with 100 and
$200 \mu \mathrm{M} \mathrm{CdCl}_{2}$ after 2, 6 and $10 \mathrm{~h}$. After $24 \mathrm{~h}$, the p-JNK levels were enhanced at all tested $\mathrm{CdCl}_{2}$ concentrations with the exception of $200 \mu \mathrm{M}$ in which case the cells likely were dead. The results of other methods (i.e. measurements of MMP, caspase activity, and DNA condensation) provided no relevant findings elucidating any mechanism likely participating in the detected increased intracellular dehydrogenase activity. The significant disappearance of MMP together with increased nuclear condensation were always found at late time periods but never during periods with the detected increased dehydrogenase activity. The detection of caspase 3 activity showed no significant differences for any treatment in comparison to control cells.

Our results proved the presence of increased ROS production after $\mathrm{CdCl}_{2}$ treatment as reported in other studies (Wang et al. 2013, Wilmes et al. 2011, Zahir et al. 1999). Although Cd toxicity is linked with a number of subcellular toxic mechanisms, recent studies have reported that the induction of oxidative stress could play an essential role in Cd-induced toxic effect (Kim and Sharma 2006, Thévenod and Friedmann 1999, Tobwala et al. 2014, Zahir et al. 1999). According to our findings on GSH depletion after $\mathrm{Cd}$ treatment, the antioxidants play an essential role in the protection against $\mathrm{Cd}$ toxicity (López et al. 2006, Zahir et al. 1999). After cellular oxidative stress becomes heightened, activation of JNK kinases occurs (Fongsupa et al. 2015) and the subsequent cellular and mitochondrial signaling can lead to apoptotic or necrotic cell death (Chambers and LoGrasso 2011). The toxic effect of $\mathrm{CdCl}_{2}$ leading to apoptosis or necrosis in kidney cells has been described in other studies (Kondo et al. 2012, López et al. 2006), but the surprising finding presented here on transient increase in intracellular dehydrogenase activity has not been described in any of those reports. Our results proved a significant relationship between increased dehydrogenase activity followed by stimulated ROS production after treatment with $\mathrm{CdCl}_{2}$ across a wide range of concentrations. It follows that $\mathrm{Cd}$ is able significantly to influence the function of mitochondria, as these constitute the main cellular sources of dehydrogenase activity and ROS production in cells. This finding could be supported by a recent study reporting an induction of mitochondrial permeability in rat mitochondria (Belyaeva et al. 2011). As a consequence of mitochondrial permeabilization, apoptotic-inducing factor (AIF) is released from the intermembrane space of mitochondria to the cytosol and caspase-independent apoptosis can thus be induced (Mao 
et al. 2007). In addition, AIF induces the expression and activation of other pro-apoptotic proteins, including caspases (Huang et al. 2017). A report has also provided evidence that $\mathrm{Cd}$ can induce a mitogen potential followed by increased cell proliferation (Templeton and Liu 2010). This phenomenon is brought about by interaction of $\mathrm{Cd}$ with mitogen-activated protein kinases (e.g. JNK and ERK), controlling cell growth, differentiation, and apoptosis (Filipič 2012, Levinthal and DeFranco 2005). Low concentrations of $\mathrm{Cd}$ can activate JNK transiently, but high doses of $\mathrm{Cd}$ induce a permanent JNK activation (Chuang et al. 2000). The activation of JNK is caused by increased ROS levels (Kamata et al. 2005). These reports could provide some justification for our finding of increased cell dehydrogenase activity, as this may be caused by a change of signaling between mitochondria and cell nucleus that likely is linked with increased ROS production. Another line of reasoning in support of our data on increased intracellular dehydrogenase activity may be related to a direct role of ROS. Some reports have indicated that increased ROS levels during oxidative stress could induce an increase in intracellular dehydrogenase activity or mitochondrial function (Chen et al. 2006, Lee et al. 2000). Other reports come up with the statement that cadmium ions affect the role of free radicals and reactive species that are formed during oxidative stress (Ďuračková et al. 2010).

In conclusion, we found that $\mathrm{CdCl}_{2}$ at high concentrations (i.e. $25-200 \mu \mathrm{M} \mathrm{CdCl}_{2}$ ) are able to induce a transient increase of cell viability in human kidney cells preceding cell death. That change in intracellular dehydrogenase activity is followed by transient increased ROS production leading to GSH depletion and other processes progressing to cell death. A number of questions remain, however, about causation and a possible role for this phenomenon associated with $\mathrm{CdCl}_{2}$. Thus, additional work is needed to elucidate this subject further, especially relating to changes in activity of the mitochondrial respiratory chain.

\section{Conflict of Interest}

There is no conflict of interest.

\section{References}

BELYAEVA EA, KOROTKOV SM, SARIS NE: In vitro modulation of heavy metal-induced rat liver mitochondria dysfunction: a comparison of copper and mercury with cadmium. J Trace Elem Med Biol 25 (Suppl 1): S63-S73, 2011.

BONHAM RT, FINE MR, POLLOCK FM, SHELDEN EA: Hsp27, Hsp70, and metallothionein in MDCK and LLC-PK1 renal epithelial cells: effects of prolonged exposure to cadmium. Toxicol Appl Pharmacol 191: 63-73, 2003.

ČAPEK J, HAUSCHKE M, BRŮČKOVÁ L, ROUŠAR T: Comparison of glutathione levels measured using optimized monochlorobimane assay with those from ortho-phthalaldehyde assay in intact cells. $J$ Pharmacol Toxicol Methods 88: 40-45, 2017.

CHAMBERS JW, LOGRASSO PV: Mitochondrial c-Jun N-terminal kinase (JNK) signaling initiates physiological changes resulting in amplification of reactive oxygen species generation. J Biol Chem 286: 16052-16062, 2011.

CHEN Q, THORPE J, DOHMEN JR, LI F, KELLER JN: Ump1 extends yeast lifespan and enhances viability during oxidative stress: Central role for the proteasome? Free Radic Biol Med 40: 120-126, 2006.

CHUANG SM, WANG IC, YANG JL: Roles of JNK, p38 and ERK mitogen-activated protein kinases in the growth inhibition and apoptosis induced by cadmium. Carcinogenesis 21: 1423-1432, 2000.

ĎURAČKOVÁ Z: Some current insights into oxidative stress. Physiol Res 59: 459-469, 2010.

FAHIM MA, NEMMAR A, DHANASEKARAN S, SINGH S, SHAFIULLAH M, YASIN J, ZIA S, HASAN MY: Acute cadmium exposure causes systemic and thromboembolic events in mice. Physiol Res 61: 73-80, 2012.

FILIPIČ M: Mechanisms of cadmium induced genomic instability. Mutat Res 733: 69-77, 2012.

FONGSUPA S, SOODVILAI S, MUANPRASAT C, CHATSUDTHIPONG V, SOODVILAI S: Activation of liver X receptors inhibits cadmium-induced apoptosis of human renal proximal tubular cells. Toxicol Lett 236: $145-153,2015$.

FOTAKIS G, TIMBRELL JA: In vitro cytotoxicity assays: Comparison of LDH, neutral red, MTT and protein assay in hepatoma cell lines following exposure to cadmium chloride. Toxicol Lett 160: 171-177, 2006. 
FUJIKI K, INAMURA H, MATSUOKA M: PI3K signaling mediates diverse regulation of ATF4 expression for the survival of HK-2 cells exposed to cadmium. Arch Toxicol 88: 403-414, 2013.

GENNARI A, CORTESE E, BOVERI M, CASADO J, PRIETO P: Sensitive endpoints for evaluating cadmiuminduced acute toxicity in LLC-PK1 cells. Toxicology 183: 211-220, 2003.

GUNNESS P, ALEKSA K, KOSUGE K, ITO S, KOREN G: Comparison of the novel HK-2 human renal proximal tubular cell line with the standard LLC-PK1 cell line in studying drug-induced nephrotoxicity. Can J Physiol Pharmacol 88: 448-455, 2010.

HAUSCHKE M, ROUŠAROVÁ E, FLÍDR P, ČAPEK J, LIBRA A, ROUŠAR T: Neutrophil gelatinase-associated lipocalin production negatively correlates with HK-2 cell impairment: Evaluation of NGAL as a marker of toxicity in HK-2 cells. Toxicol In Vitro 39: 52-57, 2017.

HUANG M, SU L, YANG L, ZHU L, LIU Z, DUAN R: Effect of exogenous TGF- $\beta 1$ on the cadmium-induced nephrotoxicity by inhibiting apoptosis of proximal tubular cells through PI3K-AKT-mTOR signaling pathway. Chem Biol Interact 269: 25-32, 2017.

IWATSUKI M, INAGEDA K, MATSUOKA M: Cadmium induces phosphorylation and stabilization of c-Fos in HK-2 renal proximal tubular cells. Toxicol Appl Pharmacol 251: 209-216, 2011.

KAMATA H, HONDA S, MAEDA S, CHANG L, HIRATA H, KARIN M: Reactive oxygen species promote TNF $\alpha$-induced death and sustained JNK activation by inhibiting MAP kinase phosphatases. Cell 120: 649-661, 2005.

KIM J, SHARMA RP: Cadmium-induced apoptosis in murine macrophages is antagonized by antioxidants and caspase inhibitors. J Toxicol Environ Health A 69: 1181-1201, 2006.

KIM SY, SOHN SJ, WON AJ, KIM HS, MOON A: Identification of noninvasive biomarkers for nephrotoxicity using HK-2 human kidney epithelial cells. Toxicol Sci 140: 247-258, 2014.

KLAASSEN CD, LIU J, DIWAN BA: Metallothionein protection of cadmium toxicity. Toxicol Appl Pharmacol 238: 215-220, 2009.

KOMOIKE Y, INAMURA H, MATSUOKA M: Effects of salubrinal on cadmium-induced apoptosis in HK-2 human renal proximal tubular cells. Arch Toxicol 86: 37-44, 2011.

KONDO M, INAMURA H, MATSUMURA K, MATSUOKA M: Cadmium activates extracellular signal-regulated kinase 5 in HK-2 human renal proximal tubular cells. Biochem Biophys Res Commun 421: 490-493, 2012.

LEE HC, YIN PH, LU CY, CHI CW, WEI YH: Increase of mitochondria and mitochondrial DNA in response to oxidative stress in human cells. Biochem J 348: 425-432, 2000.

LEE JY, TOKUMOTO M, FUJIWARA Y, SATOH M: Involvement of ubiquitin-coding genes in cadmium-induced protein ubiquitination in human proximal tubular cells. J Toxicol Sci 40: 901-908, 2015.

LEVINTHAL DJ, DEFRANCO DB: Reversible oxidation of ERK-directed protein phosphatases drives oxidative toxicity in neurons. J Biol Chem 280: 5875-5883, 2005.

LI M, PI H, YANG Z, REITER RJ, XU S, CHEN X, CHEN C, ZHANG L, YANG M, LI Y, GUO P, LI G, TU M, TIAN L, XIE J, HE M, LU Y, ZHONG M, ZHANG Y, YU Z, ZHOU Z: Melatonin antagonizes cadmiuminduced neurotoxicity by activating the transcription factor EB-dependent autophagy-lysosome machinery in mouse neuroblastoma cells. J Pineal Res 61: 353-369, 2016.

LINHARTOVÁ P, GAZO I, SAMPELS S: Combined incubation of cadmium, docosahexaenoic and eicosapentaenoic acid affecting the oxidative stress and antioxidant response in human hepatocytes in vitro. Physiol Res $\mathbf{6 5}$ : 609-616, 2016.

LÓPEZ E, ARCE C, OSET-GASQUE MJ, CAÑADAS S, GONZÁLEZ MP: Cadmium induces reactive oxygen species generation and lipid peroxidation in cortical neurons in culture. Free Radic Biol Med 40: 940-951, 2006.

MADDEN EF, AKKERMAN M, FOWLER BA: A comparison of 60, 70, and $90 \mathrm{kDa}$ stress protein expression in normal rat NRK-52 and human HK-2 kidney cell lines following in vitro exposure to arsenite and cadmium alone or in combination. J Biochem Mol Toxicol 16: 24-32, 2002.

MAO WP, YE JL, GUAN ZB, ZHAO JM, ZHANG C, ZHANG NN, JIANG P, TIAN T: Cadmium induces apoptosis in human embryonic kidney (HEK) 293 cells by caspase-dependent and -independent pathways acting on mitochondria. Toxicol In Vitro 21: 343-354, 2007. 
RIEMSCHNEIDER S, HERZBERG M, LEHMANN J: Subtoxic doses of cadmium modulate inflammatory properties of murine RAW 264.7 macrophages. Biomed Res Int 2015: 295303, 2015.

RYAN MJ, JOHNSON G, KIRK J, FUERSTENBERG SM, ZAGER RA, TOROK-STORB B: HK-2: An immortalized proximal tubule epithelial cell line from normal adult human kidney. Kidney Int 45: 48-57, 1994.

SHRESTHA S, SOMJI S, SENS DA, SLUSSER-NORE A, PATEL DH, SAVAGE E, GARRETT SH: Human renal tubular cells contain CD24/CD133 progenitor cell populations: Implications for tubular regeneration after toxicant induced damage using cadmium as a model. Toxicol Appl Pharmacol 331: 116-129, 2017.

SIMON BR, WILSON MJ, WICKLIFFE JK: The RPTEC/TERT1 cell line models key renal cell responses to the environmental toxicants, benzo[a]pyrene and cadmium. Toxicol Rep 1: 231-242, 2014.

SOMJI S, GARRETT SH, SENS MA, SENS DA: The unique N-terminal sequence of metallothionein-3 is required to regulate the choice between apoptotic or necrotic cell death of human proximal tubule cells exposed to $\mathrm{Cd}+2$. Toxicol Sci 90: 369-376, 2006.

TEMPLETON DM, LIU Y: Multiple roles of cadmium in cell death and survival. Chem Biol Interact 188: 267-275, 2010.

THÉVENOD F, FRIEDMANN JM: Cadmium-mediated oxidative stress in kidney proximal tubule cells induced degradation of $\mathrm{Na}+/ \mathrm{K}+$-ATPase though proteasomal and endo-/lysosomal proteolytic pathways. FASEB $J$ 13: 1751-1761, 1999.

TOBWALA S, WANG HJ, CAREY J, BANKS W, ERCAL N: Effects of lead and cadmium on brain endothelial cell survival, monolayer permeability, and crucial oxidative stress markers in an in vitro model of the blood-brain barrier. Toxics 2: 258-275, 2014.

VALVERDE M, TREJO C, ROJAS E: Is the capacity of lead acetate and cadmium chloride to induce genotoxic damage due to direct DNA-metal interaction? Mutagenesis 16: 265-270, 2001.

VRBOVÁ M, ROUŠAROVÁ E, BRƯČKOVÁ L, ČESLA P, ROUŠAR T: Characterization of acetaminophen toxicity in human kidney HK-2 cells. Physiol Res 65: 627-635, 2016.

WANG SS, CHEN L, XIA SK: Cadmium is acutely toxic for murine hepatocytes: effects on intracellular free Ca2+ homeostasis. Physiol Res 56: 193-201, 2007.

WANG Y, WU Y, LUO K, LIU Y, ZHOU M, YAN S, SHI H, CAI Y: The protective effects of selenium on cadmiuminduced oxidative stress and apoptosis via mitochondria pathway in mice kidney. Food Chem Toxicol 58: 61-67, 2013.

WILMES A, CREAN D, AYDIN S, PFALLER W, JENNINGS P, LEONARD MO: Identification and dissection of the Nrf2 mediated oxidative stress pathway in human renal proximal tubule toxicity. Toxicol In Vitro 25: 613-622, 2011.

ZAHIR AS, THANHTAM TV, KHALEQUZ Z: Oxidative stress as a mechanism of chronic cadmium-induced hepatotoxicity and renal toxicity and protection by antioxidants. Toxicol Appl Pharmacol 154: 256-263, 1999.

ZHANG L, MU X, FU J, ZHOU Z: In vitro cytotoxicity assay with selected chemicals using human cells to predict target-organ toxicity of liver and kidney. Toxicol In Vitro 21: 734-740, 2007.

ZIMMERHACKL LB, MOOM F, WIEGELE G, BRANDIS M: Cadmium is more toxic to LLC-PK $_{1}$ cells than to MDCK cells acting on the cadherin-catenin complex. Am J Physiol 275: F143-F153, 1998. 